Doi:10.54052/jhds.v1n3.p2 47-263

Article History

Received:20/11/2021

Accepted: $31 / 12 / 2021$

\section{CAYENNE PEPPER (Capsicum frutescens) ETHANOL EXTRACT EFFECT ON RATS SKIN WOUND HEALING AND MALONDIALDEHYDE \\ (PENGARUH EKSTRAK ETHANOL CABAI RAWIT (Capsicum frutescens) TERHADAP PENYEMBUHAN LUKADAN MALONDIALDEHYDE KULIT TIKUS)}

Dewi Ratih Handayani ${ }^{1 *}$, Linlin Haeni ${ }^{2}$, Muhammad Rizki Sukmara ${ }^{1}$ ${ }^{1}$ Department of Biochemistry and Biomolecular, Faculty of Medicine, Universitas Jenderal Achmad Yani, Cimahi, Indonesia

${ }^{2}$ Department of Histology, Faculty of Medicine, Universitas Jenderal Achmad Yani, Cimahi, Indonesia

*Corresponding author

derayani@yahoo.com

\section{ABSTRACT}

Cayenne pepper (Capsicum frutescent) is often used as spices. Cayenne pepper also has health benefits such as relieving sore muscle, pain, and toothache. Cayenne pepper contains capsaicin, vitamin A, vitamin C, antioxidants. Vitamin A also serves to epithelialize skin, and vitamin $\mathrm{C}$ works to stimulate collagen synthesis. This study was conducted to determine the effect of ethanol extract of cayenne pepper on the wound healing time and the levels of malondialdehyde (MDA) on Wistar rats skin. This study used 25 male rats Wistar strain divided into five groups. Chili extract doses used in this study used three-dose concentrations, there were $2 \%, 1 \%$, and $0.5 \%$ for seeking effective dose, which was administered for 14 days. Healing time was measured by observing the downsizing of the diameter of the wound on days 3, 7, and 14 following the phase of wound healing, and MDA levels were measured on day 14. Data were analyzed using the Kruskal-Wallis test followed by the Mann-Whitney test $(\mathrm{P}<0.05)$. The results showed that the group who were given extracts of chili with all three concentrations were 
experiencing delays in wound healing at days fourteen $(\mathrm{P}=0.01)$, and MDA levels were higher than the control group. It can be concluded that the extract of chili causes a delay in the healing process because the unmeasured dose of the extract of chili causes the release of free radicals produced by nitric oxide stimulated by capsaicin contained in chili.

Keywords: cayenne pepper; MDA; wound healing

\section{ABSTRAK}

Cabai rawit (Capsicum frutescent) sering digunakan sebagai bumbu. Cabai rawit juga memiliki manfaat kesehatan seperti meredakan nyeri otot, nyeri, dan sakit gigi. Cabai rawit mengandung capsaicin, vitamin A, vitamin C, antioksidan. Vitamin A juga berfungsi untuk epitelisasi kulit, dan vitamin C berfungsi untuk merangsang sintesis kolagen. Penelitian ini dilakukan untuk mengetahui pengaruh pemberian ekstrak etanol cabai rawit terhadap lama penyembuhan luka dan kadar malondialdehid (MDA) pada kulit tikus wistar. Penelitian ini menggunakan 25 ekor tikus jantan galur Wistar yang dibagi menjadi lima kelompok. Dosis ekstrak cabai yang digunakan dalam penelitian ini menggunakan tiga dosis konsentrasi yaitu 2\%, 1\%, dan 0,5\% untuk mencari dosis efektif yang diberikan selama 14 hari. Waktu penyembuhan diukur dengan mengamati pengecilan diameter luka pada hari ke 3, 7, dan 14 setelah fase penyembuhan luka, dan kadar MDA diukur pada hari ke 14. Data dianalisis menggunakan uji KruskalWallis dilanjutkan dengan Tes Mann-Whitney. Hasil penelitian menunjukkan bahwa kelompok yang diberi ekstrak cabai dengan ketiga konsentrasi mengalami keterlambatan penyembuhan luka pada hari keempat belas $(P=0,01)$, dan kadar MDA lebih tinggi dibandingkan kelompok kontrol. Dapat disimpulkan bahwa ekstrak cabai menyebabkan keterlambatan proses penyembuhan karena dosis ekstrak cabai yang tidak terukur menyebabkan pelepasan radikal bebas yang dihasilkan oleh nitrit oksida yang dirangsang oleh capsaicin yang terkandung dalam cabai.

Kata Kunci: cabai rawit; $M D A$; penyembuhan luka 


\section{INTRODUCTION}

Wounds are the most common injury cases. The wound itself is defined as the loss of skin integrity or the loss of part of the body's tissues. The functions of the skin include regulating water and electrolyte balance, thermoregulation, and functioning as a barrier to the external environment, including microorganisms. When this barrier is damaged due to various causes such as ulcers, burns, trauma, or neoplasms, the skin cannot perform its functions optimally. Therefore, it is essential to restore its integrity as soon as possible ${ }^{1,2}$

Wounds can be caused by several reasons, one of which is caused by: physical agent. Wounds caused by physical agents are divided into several categories, namely mechanical trauma, thermal trauma, electrical trauma, and trauma produced by ionizing radiation. One example of mechanical trauma is an open wound. The body part that is most often injured is the skin because it is located in the body's outermost layer, which functions as a barrier or protection from the outside environment.

Wound healing is divided into three phases: inflammation, proliferation, and maturation. These phases overlap each other and last from the onset of the wound to the resolution of the wound. ${ }^{3}$ Wound healing is influenced by several factors, including the drugs used.

Medicines for wound healing can be done with various kinds and types, one of which is traditional or herbal medicine. One of the reasons for using herbal medicines in the community is that, in general, herbal medicines rarely cause side effects such as chemical drugs. Wounds can trigger the formation of free radicals if the amount in excess will inhibit the wound healing process. The excess free radicals will damage cells that should have undergone wound repair. The free radicals that are formed will then undergo membrane lipid peroxidation, which, if this process occurs continuously, will form Malondialdehyde (MDA). ${ }^{4}$ This MDA is often used as a marker in assessing oxidative stress that can be measured in the blood. ${ }^{5}$

One of the plants expected to be used as herbal medicine for wound healing is chili. Chili is a plant that grows in Indonesia. Chili can be grown in both the highlands and the lowlands, so chili plants in Indonesia are very abundant. ${ }^{6}$ Chili contains organic compounds that have been identified, such as vitamin $\mathrm{A}$, vitamin $\mathrm{C}$, and antioxidant compounds called capsaicin and capsaicinol. ${ }^{5,6}$

Capsaicin has been widely studied. one result shows that capsaicin can act as an analgesic or pain reliever by inhibiting 
substance $\mathrm{P}$, which plays a role in pain delivery. ${ }^{7}$ Capsaicin has also been studied to accelerate the healing of gastric ulcers in rats exposed to indomethacin. ${ }^{8}$ Vitamin $\mathrm{C}$ is present in indomethacin. Chili can increase the stimulation of collagen formation by fibroblast cells. Vitamin A in chili is helpful in epithelial regeneration, which is very important in wound healing. Vitamin $\mathrm{C}$ derivatives, namely magnesium ascorbyl phosphate, can increase cell proliferation and synthesize collagen because collagen proliferation is essential in tissue repair. ${ }^{9}$

This study aimed to determine the effectiveness of the ethanolic extract of cayenne pepper in the wound healing process because many ingredients in chili are helpful in the wound healing process. After knowing the efficacy, I will be learned the time of wound healing and the difference in tissue MDA levels between the administration of cayenne pepper extract.

\section{METHOD}

The research used an experimental laboratory. The research subjects used 25 male Wistar rats. All rats were injured using a punch biopsy on the back with a diameter of $5 \mathrm{~mm}$, then divided into five groups. The first group was the group that did not receive any treatment. The second group was where the wound was only applied with vaseline and covered with gauze and plaster. The third group was a group of rats who applied $0.5 \%$ chili extract to the wound twice a day and covered it with gauze and plaster. The fourth group was a group of rats who applied $1 \%$ chili extract to the wound twice a day and covered it with gauze and plaster. The fifth group was a group of rats who applied $2 \%$ chili extract to the wound twice a day and covered it with gauze and plaster.

Wounds were observed on days 3, 7, and 14. On day 14, tissue malondialdehyde levels were measured using the TBARs method. The study was conducted for 14 days from the first day of injury until the wound closed. Data were analyzed using Kruskal-Wallis statistical analysis and then followed by Post Hoc Mann-Whitney.

\section{RESULT}

Effect of Cayenne Pepper Extract on Open Wound Healing in Rat Skin

\section{Observation of Open Wound Day 0}

On day 0 , the rats were injured with the same size and depth using a $5 \mathrm{~mm}$ diameter punch biopsy by removing parts of the rat skin (the epidermis and dermis) which reached a depth of approximately 2 $\mathrm{mm}$. 

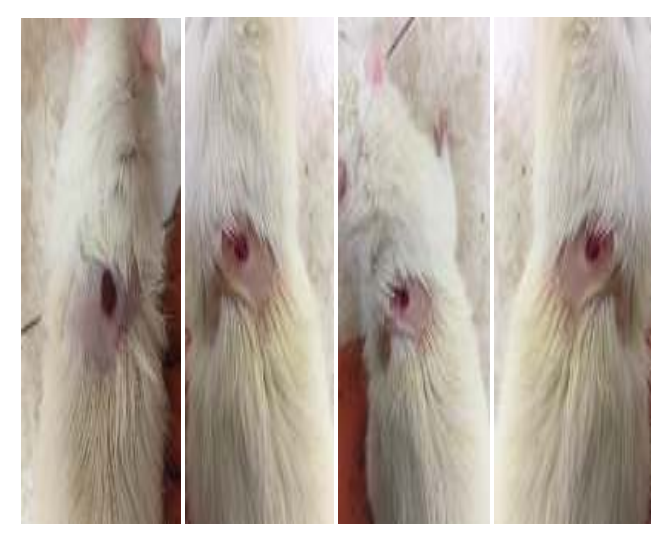

Figure 1. Wound observation day 0 .

The rats that had been injured were immediately treated according to each group and then covered with gauze. Then, It was fixed using a plaster around the rat's body so it wouldn't come off. Later, the rats were immediately put into the cage. One cage was filled with 1 rat so that the wound would not be bitten or scratched by other rats.

\section{Observation of Open Wound Day 3}

On day 3, signs of inflammation began to appear following the first healing phase, called the inflammatory phase. It was the formation of blood clots and a decrease in the diameter of the wound in each group, shown in Figure 2.
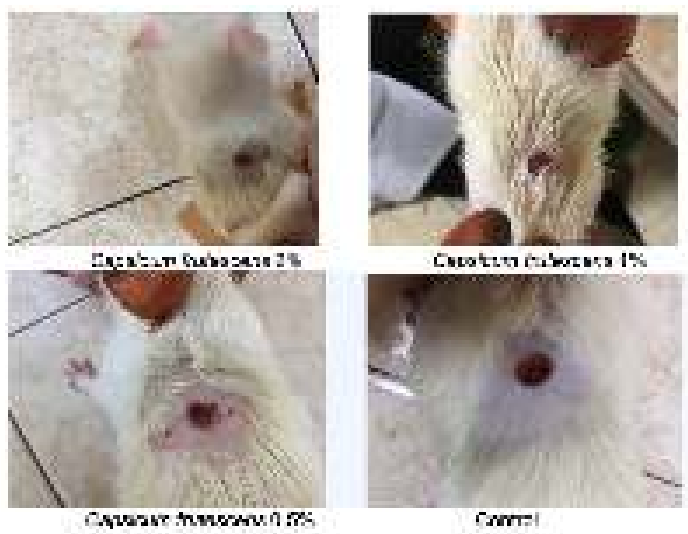

Figure 2. Wound observation day 3.

Open wounds in the $0.5 \%, 1 \%$, and $2 \%$ chili extract group showed redness around the wound and had uneven edges compared to open wounds treated with vaseline as control that had smooth edges and looked slightly blackish. Wounds had started to dry up as seen by the presence of blood clots and also visible swelling of the wounds in all groups. The wound size for all groups was the same even some wounds had been seen to shrink in some mice in each group.

\section{Observation of Open Wound Day 7}

Open wounds on day 7 were more minor than open wounds on day 3 in all groups. Wounds in all groups were pinkish, indicating the wound healing process was entering the proliferative phase. Open wound on day seven is shown in Figure 3. 


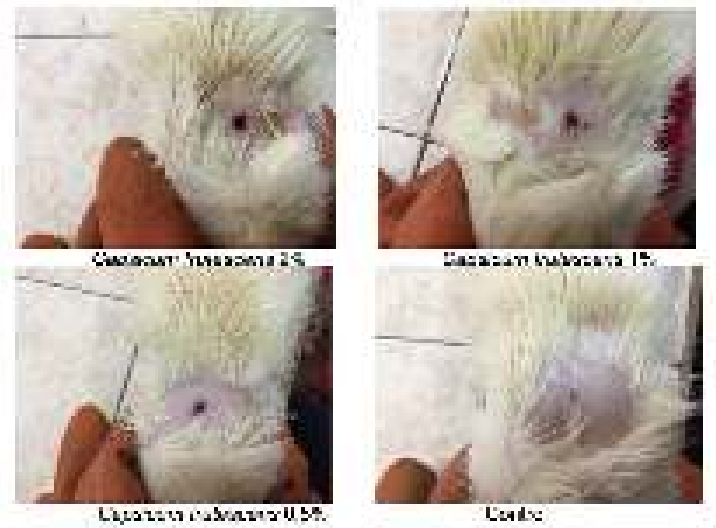

Figure 3. Wound observation day 7.

\section{Observation of Open Wound Day 14}

Open wound healing on day 14 had entered the last wound healing phase, namely the remodeling phase. It is shown in the control group, and the wound was more closed than in the other groups. The wound on day 14 is shown in Figure 4.
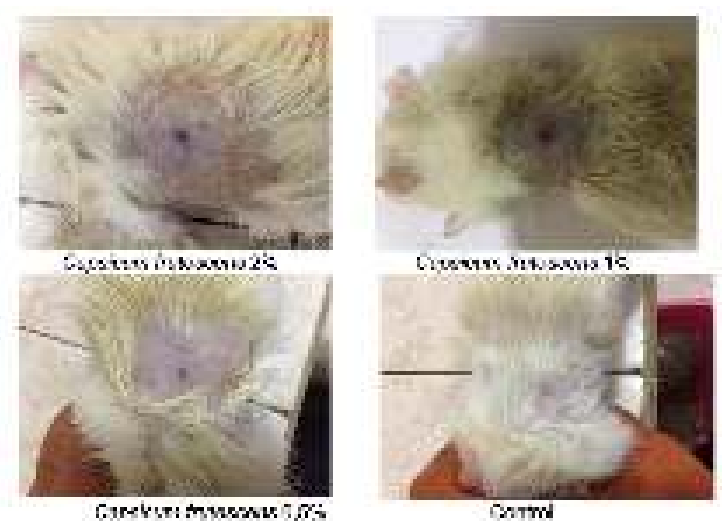

Figure 3. Wound observation day 14.

\section{The difference in Average Wound Healing Percentage}

The percentage of healing in the experimental sample was measured on days 3,7 , and 14 according to the phases of wound healing. The wound diameter was calculated using a ruler, then the difference in the wound was calculated starting from the first day, the 3rd, 7th, and 14th day. The average percentage of wound healing results are shown in Figure 5.

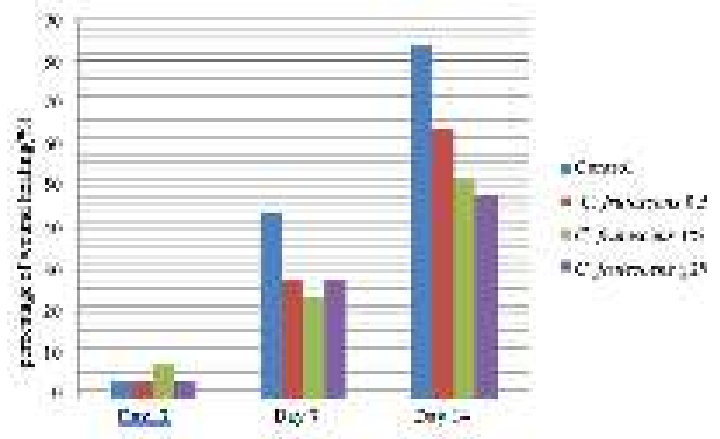

Figure 5. Average percentage of wound healing.

Table 1 shows that the percentage of wound healing on day three did not significantly differ. Because the significance value of the percentage of wound healing on day 3 was 0.05 , the results were considered insignificant. The percentage of wound healing on days 7 and 14 was considered significant because the significance value is $<0.05$. In other words, the percentage of open wound healing in rat skin was significant on day 14 . It was because the most dominant process that occurs is the process of shrinking or shrinking the wound. 
Table 1. Effect of ethanol extract of cayenne pepper to wound healing time

\begin{tabular}{|c|c|c|}
\hline Wound healing & df & $\begin{array}{l}\text { Anymp } \\
\text { Bign }\end{array}$ \\
\hline $\begin{array}{l}\text { Averaye } \\
\text { percentage } \\
\text { day } 3\end{array}$ & 3 & 0858 \\
\hline $\begin{array}{l}\text { Averaye } \\
\text { percentage } \\
\text { day } 7\end{array}$ & 3 & $0285^{+}$ \\
\hline $\begin{array}{l}\text { Averaye } \\
\text { percentage } \\
\text { day } 14\end{array}$ & 3 & $D D 1^{\circ}$ \\
\hline
\end{tabular}

Table 2 shows that there were three essential data from the overall comparison between groups. The percentage of wound healing on day three did not significantly differ in the percentage of healing. This can happen because the process is still in the inflammatory phase on day three. The percentage of wound healing on days 14 showed significance between the group and the $1 \%$ chili extract group, the control group and the $2 \%$ chili extract group, the $0.5 \%$ chili extract group, and the $2 \%$ chili extract group.

Table 2. Differences of cayenne pepper extract to wound healing time percentage

\begin{tabular}{|c|c|c|c|}
\hline \multirow[b]{2}{*}{ Q.849 } & \multicolumn{3}{|c|}{ essares ags } \\
\hline & $\begin{array}{l}\text { Wound } \\
\text { twoite } \\
\text { porsenlage } \\
\text { dxy? }\end{array}$ & $\begin{array}{l}\text { Woune } \\
\text { bewions } \\
\text { percourtage } \\
\text { say? }\end{array}$ & 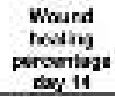 \\
\hline ustiat C. hivisos Uat & $1 \mathrm{~mm}$ & a[ts & 4002 \\
\hline rerint- $C$, senewon is & $26+3$ & arez & aste \\
\hline cerint f savous $2 \%$ & 1000 & a.15 & a DII \\
\hline 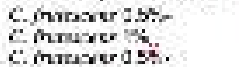 & $2 b 18$ & as 1s & swes \\
\hline 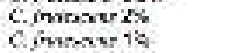 & 1000 & 250 & $d .42$ \\
\hline cimocour is & Z.51Y & as 13 & $1 \leq 40$ \\
\hline
\end{tabular}

\section{Effect of Cayenne Pepper Extract on} Tissue Malondialdehyde (MDA) Levels

The MDA level measurement was carried out in 5 groups: the negative control group, positive control, $0.5 \%$ chili extract control, $1 \%$ chili extract control, and $2 \%$ chili extract control. The average MDA levels between experimental groups are shown in Figure 6.

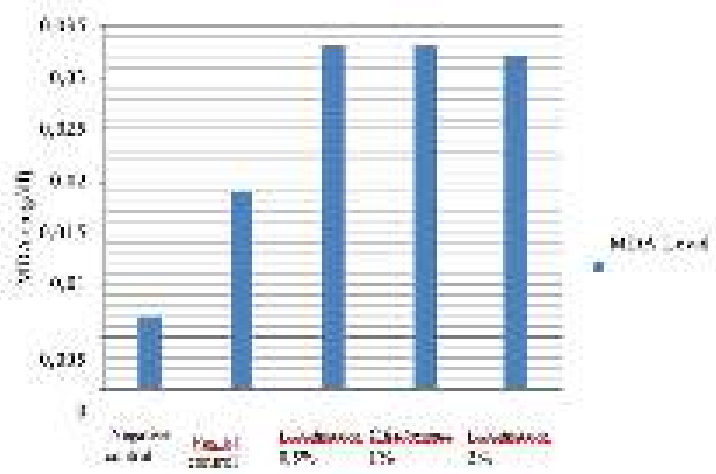

Figure 6. Average of tissue malondialdehyde (MDA) levels.

Figure 6 above shows that the average tissue MDA level in the negative control group was $0.007 \mathrm{mg} / \mathrm{dl}$. In the positive control group, it was $0.019 \mathrm{mg} / \mathrm{dl}$; in the chili extract group, $0.5 \%$ was 0.33 $\mathrm{mg} / \mathrm{dl}$, in the chili extract group. $1 \%$ was $0.033 \mathrm{mg} / \mathrm{dl}$, in the chili extract group $2 \%$ was $0.032 \mathrm{mg} / \mathrm{dl}$. The group given chili extract had higher tissue MDA levels than the other groups.

Tissue MDA levels between the negative control group, positive control, $0.5 \%$ chili extract, $1 \%$ chili extract, and $2 \%$ 
chili extract had a significant value of tissue MDA levels of 0.01 showed a significant difference between groups regarding tissue MDA levels on the day to 14 because the significance value 0.05 .

Table 3 shows that from the overall comparison between groups, there were 7 significant data. Most of the groups that showed significance were the control group, both negative and positive, with the group being given chili extract, while the comparison between groups that were given chili extract was not significantly different.

Table 3. Differences effect of cayenne pepper extract on tissue malondialdehyde (MDA) levels

\begin{tabular}{|c|c|}
\hline Croup & 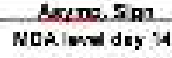 \\
\hline 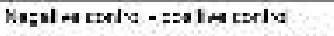 & 2019 \\
\hline knolen casing - r cutsest,is & $\sin x$ \\
\hline 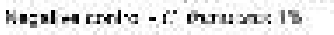 & $\sin$ \\
\hline 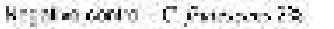 & sas: \\
\hline 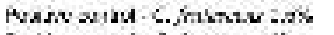 & :ond2 \\
\hline 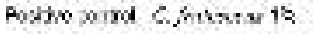 & $60)$ \\
\hline Mas.v astau - C. frabnzu is & sose \\
\hline 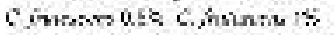 & $: 84$ \\
\hline 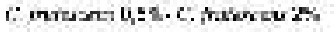 & 5893 \\
\hline 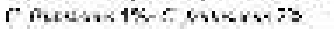 & $: 741$ \\
\hline
\end{tabular}

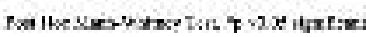

\section{DISCUSSION}

The wound looks fresh, with residual bleeding is shown in the image below at day 0 . The wound entered the first healing phase, namely the inflammatory phase, which lasted from the time the wound occurred until approximately day 5 .

Wound observation day 3 signed the first wound healing phase, namely the inflammatory phase that occurs around day 1 to day 3 . When an injury or injury occurs, the body produces a response that causes rapid activation of the coagulation pathway, resulting in blood clots. On the wound surface by platelet adhesion and aggregation. The clot contains fibrin, fibronectin, and complement components. Blood clots function to stop bleeding.

In Figure 2, it is shown that there was no fresh blood on the third day, which was different from the time of injury. In the inflammatory phase, Vascular Endothelial Growth Factor (VEGF) was released. This VEGF release process increased blood vessel permeability, making the area around the wound red and edematous. Dehydration occurs on the surface of the blood clot, forming a scab that covers the wound. In the wound area, there is necrotic tissue that causes debris. Neutrophils appear within 24 hours and secrete proteolytic enzymes that clean up trash and invade bacteria.

On day 7 , the control group showed a better percentage of wound reduction than the group that was given chili extract. On this 7th day, the second phase of wound healing is the proliferative phase. Fibroblasts and vascular endothelial cells proliferate from the first 24 hours to 72 hours of the healing process to form a specialized tissue called granulation tissue, a hallmark of wound healing. The term 
arises from its pink, smooth, and granular appearance on the wound surface. The appearance was a histological character of the presence of new blood vessels (angiogenesis) and the proliferation of fibroblasts. These new blood vessels have openings that allow the passage of plasma proteins and fluids into the extravascular space. Granulation tissue filled the wound area from day 5 to day 7 , and neovascularization was maximal. ${ }^{3.10}$

Macrophages essentially replace neutrophils at 48 to 96 hours after injury. Macrophages were vital to wound healing, clearing extracellular debris, fibrin, and other foreign bodies at the wound site and promoting angiogenesis and deposition of extracellular matrix.

In early granulation tissue, the growth factor PDGF released from degranulated platelets also plays a role in fibroblast proliferation. During the formation of granulation tissue, fibroblasts synthesized collagen deposits to fill in the tissue lost by injury and as a site for new capillaries to form. The migration process occurs towards a lower or flat because the epithelium cannot migrate to a higher place. The fibroblasts migrated to the margins of the wound along strands of fibrin fibers so that wound healing appears to be reduced or healed starting from the edge of the wound. ${ }^{10}$
It is shown in Figure 4 that the wounds in all groups had closed. The group that was given vaseline closed more lines than the group that was given chili extract. It was because the healing process given the chili extract delayed wound healing starting from the proliferative phase, where capsaicin inhibited the migration of keratinocytes. In this remodeling phase, there was a maturation process consisting of re-absorption of excess tissue, shrinkage according to the force of gravity, and finally, the re-formation of the newly formed tissue. This phase lasted for months and was declared over when all signs of inflammation have disappeared. The body tries to normalize everything abnormal due to the healing process.

Edema and inflammatory cells were absorbed, young cells matured, new capillaries closed and were reabsorbed, Excess collagen was absorbed, and the rest shrunk according to the existing strain. Scar tissue was produced pale, thin, limp, and easily moved from the base during this process.

Maximum shrinkage was shown in the wound. At the end of this phase, the appearance of a skin wound could withstand a stretch of approximately $80 \%$ of the ability of normal skin. ${ }^{3,10}$

Figure 5 shows the average percentage of wound healing in each 
experimental group. On day three, the control group had an average percentage of wound healing of $4 \%$. In other words, on day three, the $1 \%$ chili extract group had the highest average percentage of healing compared to the other groups but still not much different from the other groups. It was shown that there was no difference in healing time on day 3 of the wound healing process, namely the inflammatory phase. In the inflammatory phase, the formation of blood clots was not affected by any administration.

On day seven, the average percentage of wound healing in the control group was 44. On day seven, the average percentage of wound healing in the control group had a more significant percentage than the other groups and on day 14. The control group had the most significant percentage of wound healing by time compared to other groups, namely the average by $84 \%$.

Based on the percentage of wound healing, especially on day 14 , most of the open wounds in the control group had closed. In contrast, in the group given chili extract, especially at the highest concentration of $2 \%$, the wound did not appear to be completely closed. The control group had a better percentage of wound diameter reduction than the chili extract.

The percentage of wound healing on days 14 showed significance. It occurred because, on day seven, the wound healing process was the proliferative phase, including the keratinocyte migration process, which is helpful for wound closure. In a previous study, Illigens et al. isolated capsaicin with a concentrated dose of $0.1 \%$. They saw its effect on wound healing, resulting in a delay in wound healing in the group given capsaicin. Illigens concluded that capsaicin could inhibit keratinocytes' migration, which is helpful for the reepithelialization process. It might make the group given chili extract experience delays in wound healing compared to the control. $^{8,9}$

Most of the groups that showed significance were the control group, both negative and positive, with the group being given chili extract. The comparison between groups that were given chili extract was not significantly different. The concentrations of chili used were $2 \%, 1 \%$, and $0.5 \%$, and the capsaicin content was high.

Chili contains capsaicin, vitamin A, and vitamin $\mathrm{C}$, which function as antioxidants that inhibit the formation of free radicals. Still, the increase in tissue MDA occurred due to capsaicin in chili stimulating the release of nitric oxide. Excess levels of nitric oxide can trigger free radicals. ${ }^{5,12}$ MDA levels were higher in the group given chili extract than in the control 
group. The release of excess free radicals can also inhibit the wound healing process because free radicals are tissue-damaging, which causes the group given ethanol extract of cayenne pepper at concentrations of $0.5 \%, 1 \%$, and $2 \%$ to experience delays in wound healing time. ${ }^{11,13}$

To find out more about the effect of cayenne pepper ethanol extract on wounds. It is necessary to research histopathological descriptions and other molecular biology regarding the effect of chili extract on wound healing. It is essential to explore MDA examination according to the woundhealing phase, namely on days 3, 7, and 14 . It was necessary to research the specific substance of the cayenne pepper extracted according to the government's policy to develop herbal medicine in Indonesia. ${ }^{14,15}$

\section{CONCLUSION}

The administration of cayenne pepper ethanol extract slowed the healing process of open wounds white Wistar rats skin based on the reduction in wound diameter on days 3, 7, and 14. The administration of cayenne pepper ethanol extracts increased MDA levels of open wound tissue in the skin of white Wistar rats on day 14 .

\section{CONFLICT OF INTEREST}

We declare that there is no conflict of interest in the scientific articles.

\section{ACKNOWLEDGEMENT}

This research was funded by the LPPM Universitas Jenderal Achmad Yani, Cimahi, Indonesia.

\section{REFERENCES}

1. Atik N, Iwan J. Perbedaan efek pemberian topikal gel lidah buaya (Aloe vera $L$.) dengan solution povidone iodine terhadap penyembuhan luka sayat pada kulit mencit (Mus musculus). 2009: 2

2. Cohen IK, Diegelmann RF, Yager DR, Wornum IL, Graham M, Crossland MC. Wound care and wound healing. Dalam: Schwartz SI, Spencer S, Fischer D, Galloway, penyunting. Principles of surgery. Edisi ke-7. New York:McGrawHill; 2011: 263-96.

3. Kumar V, Cotran RS, Robbins SL. Pathologic basis of disease. Chapter 3 Tissue renewal, regeneration, and repair. $8^{\text {th }}$ ed. Philadelphia: Saunders Elsevier; 2010: 102-6.

4. Yuslianti ER, Sudjatmo AB. Pemberian madu rambutan (Nephelium lappaceum) menurunkan luas luka dan kadar malondialdehid tikus diabetes melitus. Insisiva Dental Journal. 2021; $10(1)$.

5. Papas AM. Antioxidant status, diet, nutrition, and health. United State of America: Toronto. CRC Press LLC. 1999: 1-20. 
6. Lee CY, Kim M, Yoon SW, Lee

CH. Short-term control of capsaicin on blood and oxidative stress of rats in vivo. 2013: 6 .

7. Hatta M. Aplikasi perlakuan permukaan tanah dan jenis bahan organik terhadap indeks pertumbuhan tanaman cabai rawit. Jurnal Floratek 2011; 6: 18.

8. Illigens BMW, Christopher H, Gibbons. A human model of small fiber neuropathy to study wound healing. 2013: 5.

9. Gallar J, Pozo MA, Rebollo I, Belmonte C. Effects of capsaicin on corneal wound healing. 2011: 5.

10. Mescher AL. Junqueira's basic histology. $12^{\text {th }}$ ed. United States. McGraw-Hill; 2010: 316-23.

11. Sjamsuhidajat R, De Jong Wim. Buku ajar ilmu bedah: Fase penyembuhan luka. Edisi 2. Jakarta: Penerbit Buku Kedokteran ECG; 2004: 67.

12. Yuslianti ER, Sutjiatmo AB. Rambutan honey pharmaceutical grade as potential antioxidant: Inhibit oxidized saliva malondyaldehide Malaysian Journal of Medicine and Health Sciences. 2020; 16(12).
13. Sjamsuhidajat R, De Jong Wim. Buku ajar ilmu bedah. Edisi 3. Jakarta: Penerbit Buku Kedokteran EGC. 2010: 95-102.

14. Departemen Kesehatan Republik Indonesia. Kebijakan obat tradisional nasional tahun 2007 Keputusan Menteri.

15. Dewoto HR. Pengembangan obat tradisional Indonesia menjadi fitofarmaka. Majalah Kedokteran Indonesia. 2007; 57(7): 205-2011. 